\title{
KECEMASAN DALAM PROSES BELAJAR
}

\author{
Mukholil *)
}

\begin{abstract}
Anxiety is the manifestation of mixed emotion which is expeienced by someone as a reaction toward threat, pressure, and worry which affect both physical and psychological. There are various kinds of anxiety, such as the anxiety of having done mistakes or sins; anxiety of having seen and felt danger and the anxiety in the unclear form. The symptoms of anxiety can be in the physical or psychological form. Anxiety can disturb students' learning process. However, low level anxiety can motivate students to get better achievement.
\end{abstract}

\section{Kata kunci: Kecemasan, Proses Belajar}

\section{A. PENDAHULUAN}

Kecemasan adalah masalah setiap manusia, bisa muncul setiap saat pada orang dewasa remaja ataupun anak anak di sekolah. Ada bermacam macam jenis kecemasan, ada kecemasan telah melakukan kesalahan atau dosa, kecemasan akibat melihat dan mengetahui bahaya yang mengancam dirinya dan kecemasan dalam bentuk yang kurang jelas. Gejala-gejala kecemasan ada yang muncul dan terlihat dari fisik, seperti gelisah, ekpresi wajah yang tegang, berkeringat, mulut kering, kencing terus menerus, sulit konsentrasi, tangan sering berkeringat, gangguan perut, jantung berdebar, dan merasa tegang. Selanjutnya, gejala kecemasan yang bersifat psikis di antaranya ketakuatan, pikiran kacau dan merasa malang.

Faktor faktor yang mempengaruhi proses belajar secara garis besar ada dua, yaitu faktor intern dan faktor ekstern. Di antara faktor intern yang mungkin dapat mempengaruhi proses belajar mengajar adalah rasa cemas yang muncul pada siswa ketika belajar atau ketika mengerjakan tugas lain di dalam atau di luar sekolah. Dari uraian dia atas muncul pertanyaan bagaimanakah pengaruh kecemasan dalam proses belajar?

\section{B. KECEMASAN}

Kecemasan atau anxiety pasti pernah dialami oleh semua orang, yang berbeda adalah bagaimana mereka menyikapi hadirnya perasaan ini. Ada yang mampu mengen- dalikannya namun tidak jarang yang justru mereka dikendalikan oleh perasaan ini sehingga mereka tenggelam di dalamnya. Banyak ditemui seseorang yang sukses dalam hidupnya dikarenakan dia mampu untuk menyelesaikan kecemasan. Sebaliknya banyak orang yang labil (stres) salah satu di antaranya karena tidak mampu untuk mengatasi kecemasan dalam dirinya. 
Menurut Lubis (2009:14) "kecemasan adalah perasaan yang anda alami ketika berpikir tentang sesuatu tidak menyenangkan yang akan terjadi”. Menurut Soemanto (2003:188) kecemasan yang dialami oleh anak didik, yaitu kecemasan menggambarkan keadaan emosional yang dikaitkan dengan ketakutan. Jenis yang meng- gambarkan kecemasan berbeda-beda. 1) Takut akan situasi sekolah secara menyeluruh, 2) takut aspek khusus lingkungan sekolah, guru, teman, mata pelajaran, atau ulangan dan 3) School phobia, menyebabkan anak menolak untuk pergi sekolah. Menurut Leonard's (2008:11) kecemasan adalah perasaan khawatir dan takut yang ditandai dengan perasaan tegang dan kekhawatiran berlebihan yang dialami siswa selama proses belajar mengajar berlangsung. Keadaan ini menyebabkan orang akan kehilangan penyesuaian. Dari uraian di atas disimpulkan bahwa kecemasan merupakan manisfestasi emosi yang bercampur baur dan dialami oleh individu sebagai suatu reaksi terhadap ancaman, tekanan, kekhawatiran yang mem- pengaruhi fisik dan psikis.

Kecemasan atau anxiety merupakan salah satu bentuk emosi individu yang berkenaan dengan adanya rasa terancam oleh sesuatu, biasanya dengan objek ancaman yang tidak begitu jelas (Sudrajat, 2008:1). Kecemasan yang menyertai kejadiankejadian tidak menyenangkan dapat menciptakan suatu berkas ingatan kuat yang mengandung rekaman peristiwa itu dan juga reaksi fisik yang menyertai peristiwaperistiwa itu (Wood dkk, 2007:186).

Kecemasan dengan intensitas yang wajar dapat dianggap memiliki nilai positif sebagai motivasi. Apabila intensitasnya sangat kuat dan bersifat negatif, justru malah akan menimbulkan kerugian dan dapat mengganggu terhadap keadaan fisik dan psikis individu yang bersangkutan.

\section{Macam-Macam Kecemasan}

Kecemasan yang dialami oleh siswa berbeda-beda karena kecemasan merupakan salah satu bentuk emosi individu yang berkenaan dengan adanya rasa terancam oleh sesuatu, biasanya dengan objek ancaman yang tidak begitu jelas. Kecemasan dapat dialami siapa pun dan di mana pun, termasuk juga para siswa di sekolah. Kecemasan yang dialami siswa di sekolah bisa berbentuk kecemasan objektif, neurotik (saraf) atau kecemasan moral (Soelaeman, 2005:105).

Berkaitan dengan kecemasan moral yang merupakan kecemasan terhadap hati nurani, Chomaria (2009:153) menyatakan bahwa ada korelasi negatif yang signifikan antara keteraturan menjalankan salat dengan kece- masan. Makin teratur seorang menjalankan shalat makin rendah tingkat kecemasan. Selain salat yang dilakukan seorang yang mengalami kecemasan moral bisa dilakukan dengan cara berdoa, berzikir, meditasi untuk menjadikan hidup lebih 
bermakna dan bahagia secara spiratual. Dengan memberikan suntikan spiratual, doa menjadikan penyembuh beragam kegelisahan yang hadir dalam kehidupan kita sehari-hari seperti kecemasan, ketakuatan dan lainnya.

Ada tiga kecemasan (Suyantini, 2010:9) yaitu: 1) kecemasan yang disebabkan merasa berdosa atau merasa bersalah. Misalnya sesorang melakukan sesuatu yang bertentangan dengan hati nuraninya atau keyakinannya. Seorang pelajar menyontek, pada waktu pengawas ujian lewat di depanya berkeringat dingin, takut diketahui. 2) Kecemasan karena akibat melihat dan mengetahui bahaya yang mengancam dirinya. Misalnya kendaraan yang dinaiki remnya macet, menjadi cemas kalau terjadi tabrakan beruntun dan ia sebagai penyebabnya. 3) Kecemasan dalam bentuk yang kurang jelas, apa yang ditakuti tidak seimbang, bahkan yang ditakuti itu hal/benda yang tidak berbahaya. Rasa takut sebenarnya sesuatu perbuatan yang biasa/wajar kalau ada sesuatu yang ditakuti dan seimbang. Bila takut yang sangat, luar biasa dan tidak sesuai terhadap objek yang ditakuti sebenarnya patologis yang disebut phobia. Phobia adalah rasa takut yang sangat atau berlebihan terhadap sesuatu yang tidak diketahui lagi penyebabnya.

Dari uraian di atas dapat disimpulkan bahwa macam-macam kecemasan, yaitu kecemasan yang bersifat objektif, misalnya: menyadari bahaya sedang mengancam dirinya, tidak realistik (neurotis) dan berdasarkan hati nurani meliputi: moral, merasa bersalah, merasa bersalah/berdosa.

\section{Gejala-gejala Kecemasan}

Gejala gejala kecemasan secara umum dapat dibedakan menjadi dua hal, yaitu fisik dan psikis. Menurut Wood dkk (2007:186) ada beberapa gejala-gejala kecemasan yang bersifat fisik, yaitu gelisah, pegal-pegal, kedutan pada kelopak mata, ekpresi wajah yang tegang, berkeringat, mulut kering, kencing terus menerus, sulit konsentrasi, tangan sering berkeringat, gangguan perut, jantung berdebar, rasa tersumbat, pada tenggorokan. Selanjutnya gejala bersifat psikis: Ketakutan, pikiran kacau dan merasa malang. Soemanto (2003:188) menyatakan bahwa ada beberapa indikator fisik dalam kecemasan, yaitu sakit kepala, sakit perut tanpa ada sebab fisik serta menggigit kuku, berkeringat, berbicara tersendat-sendat. Selanjutnya, indikator psikis dalam kecemasan yaitu kikuk, tidak bisa diam, kebingungan.

Menurut Froggatt dalam (Supriyantini, 2010:12) gejala yang muncul dari rasa cemas, yaitu: jantung berdebar-debar, denyut nadi meningkat, napas pendek atau perasaan tercekik, kedinginan, rasa panas, dada sakit, berkeringat, gemetar, rasa kebal/mati rasa atau kesemutan, mual atau sakit perut, pusing, kepala terasa ringan, pingsan, tidak stabil, merasa takut mati, kehilangan kendali atau 
menjadi gila. Rasa cemas seperti itu dan gejala kecemasan yang muncul, biasa membuat orang stres. Ia biasa merasa terganggu dalam pekerjaan, fungsi pribadi, maupun fungsi sosial di tengah masyarakat.

Menurut Priest (dalam Lubis, 2009:15) pada saat menghadapi kecemasan tubuh mengadakan reaksi fisik meliputi: 1) berdebar-debar karena ketika di bawah pengaruh stres, seseorang akan merasa jantung terpacu dengan cepat. 2) gemetar; tangan atau lutut gemetar ketika berusaha melakukan sesuatu dan ter- huyung-huyung. 3) Tegang; tanda yang paling utama dari kecemasan adalah ketegangan. Ketika saraf di belakang leher sangat kencang dan menegang, dan ini akan menyebabkan rasa tersiksa. Ketegangan saraf pada kulit kepala, merupakan salah satu penyebab timbulnya pusing yang akan mengantarkan pada keresahan. 4) Gelisah atau sulit tidur; dan mungkin merasa kesulitan jika akan tidur. 5) Keringat terlalu banyak, seperti pada hari yang panas. Tanda tanda fisik lain dari kecemasan dan ketegangan dapat berupa gatal-gatal pada tangan dan kaki, juga selalu ingin buang air kecil tak seperti biasanya.

Dari uraian di atas dapat disimpulkan bahwa gejala-gejala yang bersifat psikis adalah gangguan sistem saraf, berdebardebar, sesak nafas, berkeringat, telapak tangan dan kaki dingin, kelelahan fisik, sakit kepala, mulut kering dan pencernaan tidak sempurna. Kemudian yang termasuk gejala- gejala yang bersifat psikis adalah gangguan tidur (mimpi buruk), tidak mampu memusatkan perhatian, perasaan sensitif (mudah merasa malu dan tegang, mudah khawatir dan takut, tidak tenang dan cepat bingung, bersikap pesimis dan tidak percaya diri dan merasa tidak bahagia.

\section{Faktor-faktor Penyebab Kecemasan}

Pada dasarnya setiap individu selalu berusaha untuk mengatasi kecemasan dengan cara melakukan penyesuaain terhadap sebabsebab timbulnya rasa cemas. Reaksi kecemasan ini menggambarkan perasaan subjektif yang muncul dalam bentuk ketegangan yang tidak menyenangkan.

Menurut Burnham (dalam Supriyantini, 2010:13), sumber rasa cemas akan lebih mudah ditelusuri dengan meneliti 3 penyebab dasar, yaitu: 1) rasa percaya diri yang mungkin terancam oleh keraguan akan penampilan lahiriah maupun kemampuan. 2) Kesejahteraan pribadi kita mungkin terancam oleh ketidakpastian akan masa depan, keraguan dalam pengambilan keputusan dan keprihatinan akan materi. 3) Kesejahteraan kita mungkin terancam oleh berbagai konflik yang tidak terpecahkan.

Menurut Sudrajat (2008:13) banyak faktor-faktor pemicu timbulnya kecemasan pada diri siswa. Misalnya, target kurikulum yang terlalu tinggi, iklim pembelajaran yang tidak kondusif, pemberian tugas yang padat, dan sistem penilaian ketat dan kurang adil. 
Hal itulah di antaranya yang menjadi faktor penyebab timbulnya kecemasan yang bersumber dari faktor kurikulum. Begitu juga, sikap dan perlakuan guru yang kurang bersahabat, galak, judes dan kurang kompeten merupakan sumber penyebab timbulnya kecemasan pada diri siswa yang bersumber dari faktor guru. Penerapan disiplin sekolah yang ketat dan lebih mengedepankan hukuman, iklim sekolah yang kurang nyaman, serta sarana dan prasarana belajar yang sangat terbatas juga merupakan faktor-faktor pemicu terbentuknya kecemasan pada siswa yang bersumber dari faktor manajemen sekolah.

\section{BELAJAR DAN PRESTASI BELAJAR}

Belajar adalah suatu proses perubahan tingkah laku seseorang. Hal ini sesuai pendapat Wittig (dalam Hakim, 2000:65) bahwa belajar adalah perubahan yang relatif menetap yang terjadi dalam segala macam atau keseluruh tingkah laku suatu organisme sebagai hasil pengalaman. Hal belajar dapat didefinisikan sebagai proses perubahan tingkah laku melalui latihan. Dari pendapat yang telah diuraikan, belajar merupakan tahapan suatu perubahan seluruh tingkahlaku individu berupa pengetahuan, pemahaman, keterampilan, dan juga sikap yang relatif menetap sebagai hasil dari pengalaman, latihan, serta interaksi dengan lingkungan yang melibatkan proses kognitif.

Belajar merupakan suatu proses yang melahirkan perubahan tingkah laku sehingga seorang akan mempunyai sikap atau cara yang berbeda dengan sikap atau cara sebelum belajar. Slameto (2003:2) mengemukakan "Belajar ialah suatu proses usaha yang dilakukan individu untuk memperoleh suatu perubahan perilaku yang baru secara keseluruhan, sebagai hasil dari pengalaman individu itu sendiri dalam interaksi individu lingkungannya".

Berdasarkan pendapat tersebut dapat dijelaskan bahwa belajar adalah serangkaian kegiatan jiwa raga untuk memperoleh suatu perubahan tingkah laku sebagai hasil dari pengalaman individu dalam interaksi dengan lingkungannya yang menyangkut kognitif, afektif, dan psikomotor. Setiap kegiatan yang dilakukan harus direncanakan terlebih dahulu untuk mencapai tujuan yang telah ditentukan. Pencapaiaan tujuan tersebut tergantung bagaimana pelaksanaan atau proses kegiatan berlangsung. Begitu juga dengan kegiatan belajar mengajar di sekolah, keberhasilan dalam proses belajar mengajar tergantung bagaimana proses belajar mengajar tersebut berlangsung. Untuk mengetahui keberhasilan proses belajar mengajar dapat dilihat dari prestasi belajar yang dicapai siswa.

Prestasi belajar merupakan hasil yang dicapai atau diperoleh dari suatu usaha yang telah dilakukan yang menunjukkan tingkat 
keberhasilan seseorang dalam proses belajarnya, dikatakan berhasil jika prestasi yang didapat seorang siswa memenuhi standar ketuntasan belajar yang telah ditetapkan. Menurut Badudu (2003:285) "prestasi adalah hasil yang dicapai dari apa yang dikerjakan atau sudah diusahakan". Menurut Syah (2003:213) prestai belajar adalah pengung- kapan hasil belajar yang berdimensi cipta (kognitif), rasa (afektif), maupun karsa (psikomotor) yang dinyatakan kedalam ukuran dan data hasil belajar. Prestasi belajar itu sendiri adalah proses akhir dari belajar yang digambarkan dengan nilai berupa angka atau simbol.

\section{Faktor-faktor yang Mempengaruhi Prestasi Belajar}

Faktor yang dapat mempengaruhi hasil prestasi belajar peserta didik di sekolah, secara garis besar dapat dibedakan menjadi dua bagian yaitu faktor internal dan faktor eksternal. Menurut Slameto (2010:54) “faktor internal adalah faktor pada diri sendiri meliputi kesiapan mental dan fisik, kecemasan, sikap terhadap pendidikan, kebiasaan belajar, motivasi, kesehatan, umur dan jenis kelamin dan faktor eksternal adalah Faktor di luar siswa, karekteristik pengajar, situasi belajar mengajar, fasilitas fisik dan lingkungan belajar".

Selanjutnya, faktor-faktor yang mempengaruhi keberhasilan belajar di sekolah antara lain menurut Hakim (2005:44) 1) tegaknya disiplin sekolah secara konsisten, 2) adanya guru yang berkompeten, 3) kondisi gedung sekolah, yaitu letak gedung di lingkungan yang kondusif, 4) adanya fasilitas belajar yang memadai dan 5) waktu belajar di sekolah, sebaiknya dilakukan di pagi hari.

Matematika merupakan simbolis dan ciri utamanya adalah penggunaan cara bernalar/berpikir deduktif, tetapi tidak merupakan cara bernalar induktif. Pendapat ini sesuai dengan pembelajaran matematika yang diberikan pada semua sekolah karena matematika memang banyak diberikan kepada siswa dengan menggunakan banyak simbol baik dari segi penulisannya maupun makna yang juga berbeda-beda.

Belajar matematika sangatlah penting diajarkan kepada siswa di sekolah karena berguna dan bermanfaat untuk mencerdaskan generasi penerus bangsa dalam memecahkan suatu masalah yang menyangkut pengembangan kehidupan sehari-hari. Hal ini sejalan bahwa matematika perlu diajarkan kepada siswa karena selalu digunakan dalam segala segi kehidupan. Semua bidang studi memer- lukan keterampilan matematika yang sesuai. Keterampilan matematika merupakan saran komunikasi yang (kuat, singkat, dan jelas) dapat digunakan untuk menyajikan informasi dalam berbagai cara. Juga dapat meningkatkan kemampuan berpikir (logis, ketelitian, dan kesadaran ruang), dan memberikan kepuasaan terhadap pemecahan masalah yang menentang. 
Prestasi belajar suatu mata pelajaran diperoleh setelah siswa melakukan kegiatan belajar di sekolah. Prestasi tersebut diperoleh berdasarkan hasil evaluasi yang dilakukan guru mata pelajaran yang bersangkutan. Prestasi belajar tersebut memberikan informasi kepada siswa dan guru tentang keberhasilan belajar yang telah diraih.

\section{PENGARUH KECEMASAN DALAM PEMBELAJARAN}

Kecemasan adalah salah satu bentuk emosi individu yang berkenaan dengan adanya rasa terancam oleh sesuatu, biasanya dengan objek ancaman yang tidak begitu jelas. Kecemasan dengan intesitas yang wajar dapat dianggap memiliki nilai positif sebagai motivasi. Apabila intesitasnya sangat kuat dan bersifat negatif, justru malah akan menimbul- kan kerugian dan dapat mengganggu terhadap keadaan fisik dan psikis individu yang bersangkutan.

Sudrajat (2008:3) mengatakan bahwa banyak faktor-faktor pemicu timbulnya kecemasan pada diri siswa. Target kurikulum yang terlalu tinggi, iklim pembelajaran yang tidak kondusif, pemberian tugas yang padat, serta sistem penilaian ketat dan kurang adil dapat menjadi faktor penyebab timbulnya kecemasan yang bersumber dari faktor kurikulum. Begitu juga, sikap dan perlakuan guru yang kurang bersahabat, galak, judes dan kurang kompeten merupakan sumber penyebab timbulnya kecemasan pada diri siswa yang bersumber dari faktor guru. Penerapan disiplin sekolah yang ketat dan lebih mengedepankan hukuman, iklim sekolah yang kurang nyaman, serta sarana dan prasarana belajar yang sangat terbatas juga merupakan faktor-faktor pemicu terbentuknya kecemasan pada siswa yang bersumber dari faktor manajemen sekolah.

Kecemasan dapat membangkitkan motivasi siswa untuk mencapai target belajar atau hasil belajar. Namun, di sisi lain kecemasan yang berlebihan atau tingkat kecemasan tinggi tentu akan menggangu dalam proses belajar yang mengkhawatirkan akan prestasinya itu sendiri. Untuk itu ada kemungkinan, yaitu: 1) Siswa-siswa yang dengan tingkat kecemasan yang rendah berprestasi lebih baik daripada siswa dengan tingkat kecemasan yang tinggi sesuai dengan pendapat Spielbelger (dalam Kristiawan, 2003:20). 2) tingkat kecemasan yang rendah biasanya mendorong belajar, sedangkan tingkat kecemasan yang tinggi mengganggu proses belajar siswa belajar. 3) siswa-siswa dengan tingkat kecemasan yang rendah lebih merasa aman dalam menghadapi tes daripada siswa yang tingkat kecemasannya tinggi. 4) Bila siswa cukup mengenal jenis tes yang akan dihadapi maka kecemasan akan berkurang. 5) Pada tes-tes yang mengukur daya ingat, siswa-siswa yang cemas memberi hasil-hasil yang lebih baik dari pada siswa yang kurang cemas. 6) Kecemasan terhadap tes bertambah bila hasil tes untuk 
menentukan tingkat-tingkat siswa (Kirkland dalam Kristiawan, 2003:21).

\section{E. PENUTUP}

Kecemasan merupakan manisfestasi emosi yang bercampur baur dan dialami oleh individu sebagai suatu reaksi terhadap ancaman, tekanan, kekhawatiran yang mempengaruhi fisik dan psikis. Kecemasan pada tingkat yang rendah dapat mendorong siswa belajar. Siswa lebih merasa aman dalam menghadapi tes, memberi hasil-hasil yang lebih baik daripada siswa yang kurang cemas. Selanjutnya, tingkat kecemasan yang tinggi dapat mengganggu proses belajar siswa belajar. Siswa kurang merasa aman ketika menjalani tes, dan dapat mempengaruhi hasil belajar siswa.

\section{DAFTAR RUJUKAN}

Chomaria, Nurul 2009. 2009. Tips Jitu dan Praktis Mengusir Stress, Yogyakarta: DIVA Press.

Hakim, Thursan. 2005. Belajar Secara Efektif. Jakarta: Puspa Swara.

Kristiawan. 2003. Hubungan Kecemasan Pada Bidang Stusi Matematika Terhadap Prestasi Belajar Matematika Siswa pada Kelas II SLTP Negeri 2 Gondang Tulung
Agung. Skripsi tidak diterbitkan. Surabaya: Universitas PGRI ADI Buana.

Leonard's. 2008. Pengaruh Konsep diri, Sikap Siswa pada pada Matematika dan kecemasan Siswa terhadap Hasil Belajar Matematika (Survei pada SMP di Wilayah DKI Jakarta. (Daring). Tersedia: http//www. namadomaincom/ndban_big.gif (24 Agustus 2017).

Slameto. 2003. Belajar dan Faktor Faktor yang Mempengaruhinya. Jakarta: PT Reniuka Cipta.

Soelaeman, M. Munandar. 2005. Ilmu Budaya Dasar. Bandung: Refika Adima.

Soemanto, Wasty. 2003. Psikologi Pendidikan. Jakarta: Rineka Cipta.

Sudrajat, Akhmad. 2008. Upaya Mencegah Kecemasan Siswa di Sekolah. (Daring) Tersedia: http//www. Akhmadsudrajat.wordpress.com. (25 Agustus 2017).

Suyantini. 2010. Perbedaan Kecemasan dalam Menghadapi Ujian Antara Siswa Program Reguler dengan Siswa Akselerasi. (online). Tersedia: $\mathrm{http} / / \mathrm{www} \cdot$.responsitoryusu. ad.id/bitsteam /123456789pdf. (25 Agustus 2017.

Syah, Muhibbin. 2003. Psikologi Belajar. Jakarta: PT Raja Grafindo Persada.

Wood dkk. 2007. Kiat Mengatasi Gangguan Belajar. Yogjakarta: Kata Hati. 